\title{
Community based design approach as initial stage to promote urban composting from a Hill Station of the Philippines
}

\author{
${ }^{1 *}$ Lunag, Marcelino Jr N., ${ }^{2}$ Elauria, Jessie C., ${ }^{3}$ Burguillos, Juanito D., \\ ${ }^{1,3}$ Saint Louis University, Department of Mechanical Engineering, Bonifacio St. Baguio City, \\ Philippines, 2600 \\ ${ }^{2}$ University of the Philippines Los Baños, Institute of Agricultural Engineering, College of Engineering \\ and Agro-Industrial Technology, Laguna, Philippines, 4027
}

*Corresponding author email address: mnlunagjr@slu.edu.ph

\begin{abstract}
:
Baguio City is the only American hill station in Asia, which was called the "City of Pines" and became the favorite summer capital in the Philippines. The city was designed by world renowned Chicago architect Daniel Burnham intended initially for 25,000 people, but now, bursting at it seems to 342,200 households due to unsustainable urbanization resulting to a problematic uncontrolled pile-up of municipal waste. Biodegradables comprise the largest form of garbage at $41.67 \%$ which can be processed to a valuable product. Composting is the most cost-effective method for this purpose however compliance to it is very low due to increasing population. As such, this study was conducted as initial approach to promote urban composting by involving stakeholders at the early design stages. The preferences of the participants $(\mathrm{N}=384)$ in terms of design features of the compost bin such as color, capacity, aeration, odor control, mobility, signage, cost and each underlying factors associated were determined. Moreover, a linear correlation ( $\mathrm{r}$ squared $=0.7382$ ) between population density and composting compliance was established. Furthermore, most of the household and barangay officials suggest that composting should be done both at source and the barangay to be effective. The role of community involvement will have a significant contribution in alleviating the city's burgeoning expenditure in collecting, hauling, and energy usage in converting these left-overs. This study gives new insights for initial planning of city government to encourage urban composting and assess its sustainability as key intervention for a functional bio waste management system.
\end{abstract}

Keywords: unsustainable urbanization, community involvement, composting compliance, initial planning, hill station

Graphical Abstract

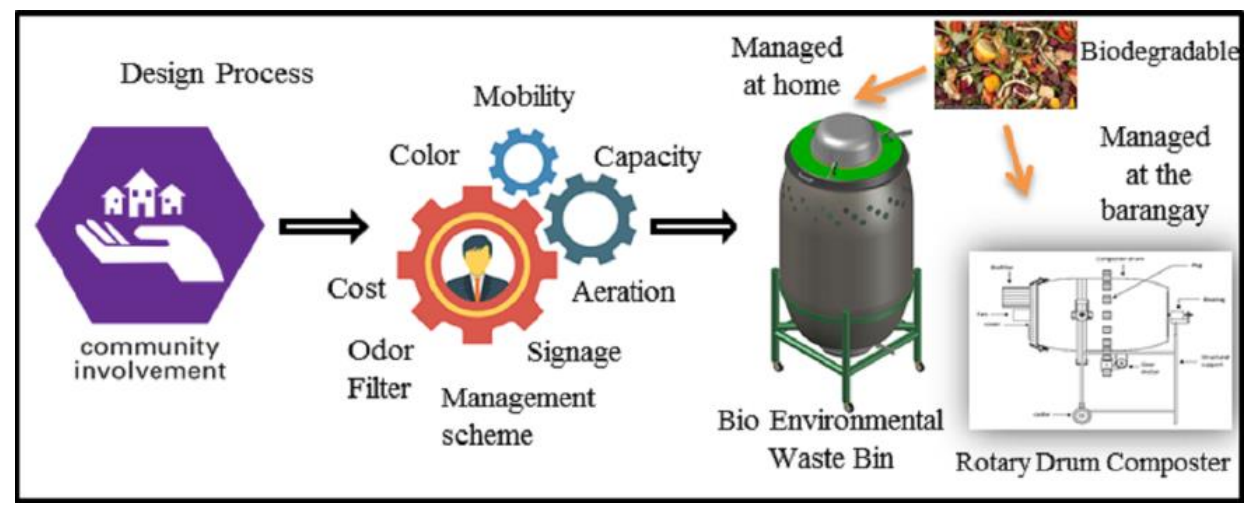




\section{Introduction}

The household is the smallest unit and yet the most important in society. With the advent of urbanization, the need for the cumulative effort of every family in attaining a green initiative city is imperative. A developing country like the Philippines has biodegradables as the significant component in its municipal solid waste at $52.31 \%$ which mainly generated by the residential sources at $56.7 \%$ of the total waste generators (EMB - DENR, 2015). The right disposal and treatment of these wastes is the prevailing challenge the world faces towards sustainability (Oliveira et al., 2017) because most developing nations rely heavily on informal workers, who collect, sort, and recycle at least $15 \%-20 \%$ of generated waste as a means of waste recovery (World Bank, 2019).

Baguio City, the only American hill station in Asia region, is an upland retreat and recreation center of the American colonizers during the $19^{\text {th }}$ century in which later became the nation's summer capital because of its cold climate ranging from 15 to 23 degrees Celsius (Crossette, 1998; Doronila, 2009; Estoque \& Murayama, 2013a; Reed, 1999). Today, Baguio is now a bustling city evolved into a business hub, important educational center, and a favorite tourist destination spot drawing people from different culture around the globe. With population rises that doubles and even triples during peak events; thus, waste generation also increases. According to (Baguio City Government, 2015), Biodegradable waste comprises the largest, which is almost half of the total municipal solid waste peaking up to $41.67 \%$ generated from different sources. Biomaterials made in the household are food waste, kitchen scrap, and yard or garden waste, if managed properly, then half of the problem will be solved (Lim, 2015). Under Republic Act 9003, Composting is a mandatory method of waste diversion of organic material into a valuable product through a biological process. With home composting strategy, it is believed to encourage community to participate in this environmental endeavor as a means of reducing the quantity of waste and producing quality compost (Adhikari, Trémier, Martinez, \& Barrington, 2012; Fan et al., 2018; Lekammudiyanse \& Gunatilake, 2009; Masebinu et al., 2016; Vázquez \& Soto, 2017).

Studies also show how composting can be sustainable in the field of agriculture. According to Pergola et al., (2018), stabilized organic matter can restore the fertility of the soil and can replace the use of chemical fertilizers. Moreover, it was reinforced through a soil bioremediation process using food waste compost, as mentioned by Cerda et al., (2018). With this, Advancement in composting technology increases and have become invaluable due to its environmental compatibility (Onwosi et al., 2017). Composting at home reduces the emissions of greenhouse gases and odor problems released by this food wastes during collection, hauling and disposal stages (ADB, 2017; Guidoni et al., 2018; Lim, 2015), therefore different compost bin type emerges from household as a means of mitigation which varies from simple to durable storage designs. Literature available such as the simple composting method in the Philippines which uses recycled materials such as coconut shell stack, compost pits, tire towers, and plastic sacks (EMB - DENR, 2015). In Sri Lanka, some of durable waste compost bin were created that made up of wood, plastic, and concrete (Practical Action South Asia, 2008). While in Greece, the residents of the town have a preferred waste bin design were for their organic matter (Keramitsoglou \& Tsagarakis, 2018). Centralized facility was also introduced as an option for 
large scale composting; the problem for this method is that not $100 \%$ guarantee that all household will segregate biodegradable to non-biodegradables, which requires to have mechanical separator which is quite expensive, also, even if this machine is efficient, the compost feed is often contaminated by glass, metals, plastic, etc. (ADB, 2017).

The design of composting scheme to cater specifically organic materials is a vital issue in solid waste management as a practical approach between household and the city's waste services. According to the World Bank (2019), public participation is key to a functional waste system. Despite the advantages of composting and the existing comprehensive law in the country mentioned above, the implementation in the city is dismal due to the following issues: 1) weak execution and low participation of different local government units (Castillo \& Otoma, 2013; Sapuay, 2005), 2) Limited available space mainly due to urban sprawl (Estoque \& Murayama, 2013b; Gonzales, 2016), 3) Odor problems (Harrison, 2007; Wilmink \& Diener, 2001), and 4) Biodegradable waste are mixed with residual (mostly cellophane and other plastic containers (DENR, 2019). Thus, this research study seeks to involve stakeholders regarding preferred composting scheme or system and design of the waste bin as an initial stage of encouragement to composting towards a sustainable environment. Furthermore, it allows the determination of the underlying factors associated with a low compliance level of biodegradable waste composting in the city.

\section{Materials and Methods}

This study seeks first the permission of the League of the Barangay in order that the Barangay Captains will support this endeavor and that participants will voluntarily relay the needed information's. The participants were asked for their consent before the conduct of interview and questionnaire.

\subsection{Study Area and Situation}

The city on top of the mountain is geographically located in the south of the central part of Benguet Province in the Cordillera Administrative Region (CAR) as shown in Figure 4. The developed portion of the city corresponds to a plateau that rises to an elevation of 1400 meters. Total land area is 57.49 square kilometers enclosed in a perimeter of 30.6 kilometers, and approximately, the city is 250 kilometers north of Manila. Majority of the land use is the residential areas $(56.35 \%)$, and therefore, the most dominant among all the public uses as shown in Figure 5. In terms of topography, the city has a slope of gentle to moderately steep with incline less than 30 percent. 



Figure 4. The map of the study showing the geographical location and the clustered sampling areas

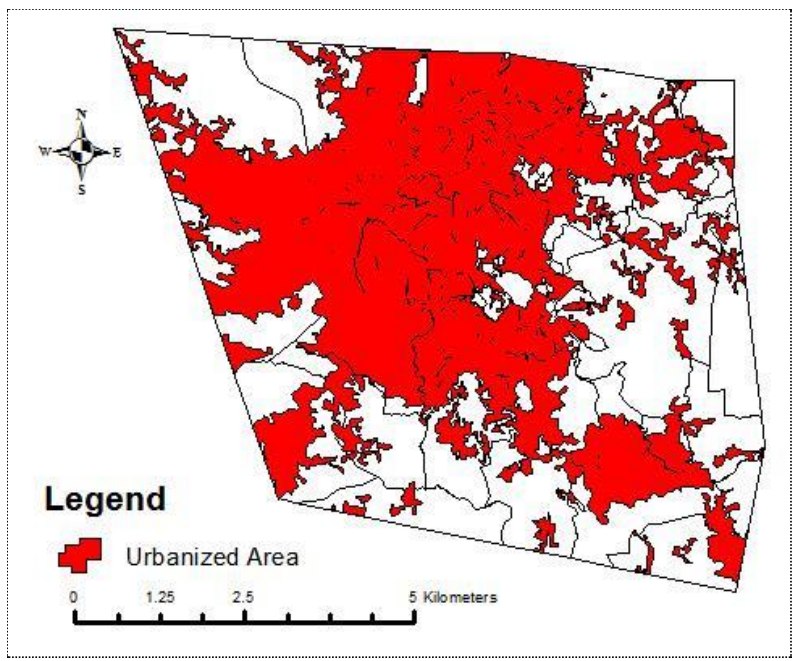

Figure 5. The map of Baguio showing the extent of urbanization in the city

There are 128 total administrative barangays in which it was clustered into 16 groups (BaguioCity Planning and Development Office, 2014). Figure 6 shows the computed household population density of different clusters from A to $\mathrm{P}$ given by the Philippine Statistics Authority (PSA). The population rises to 345,366, exceeding the 25,000 designed capacity of the city considerably. With increasing population, Estoque \& Murayama (2014) mentioned that the town 
is now towards "unsustainable urbanization" concerning environmental and eco-sustainable human development perspectives.

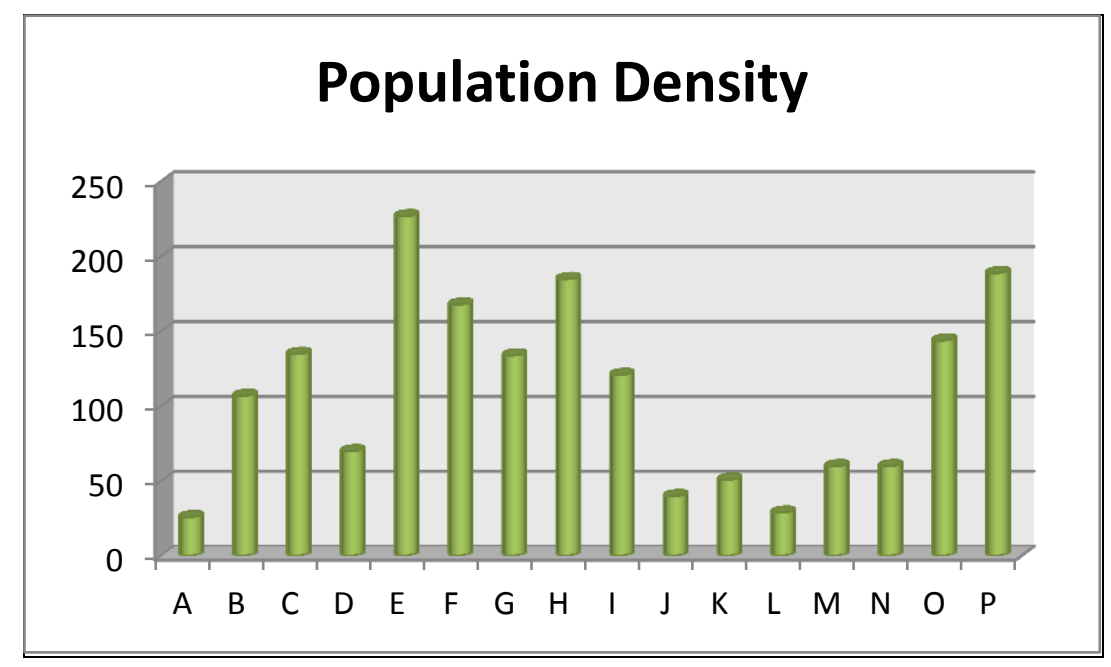

Figure 6. Population density of different clustered village/Barangay

Baguio City is also the home of the famous flower festival in the Philippines which draws people around the globe during peak seasons such as Christmas, Lenten and summer vacations. As the population increases, so does garbage generation. City's waste composition is characterized by 41.7 percent biodegradables with approximately 142 tons generation per day coming from residential areas, 33.8 percent recyclables, 24.1 percent residuals, and 0.4 percent special wastes. Solid wastes are collected via the city's government fleet of 14 units of six-wheeler trucks and two groups of ten-wheeler vehicles. Household wastes from barangays are levied once a week while solid waste collection in the Central Business District (CBD) and the public market are done twice a day and once a day in institutional areas. There is an ordinance which is the Ord 18 Section 194 series of 2016 that mandates the "No Segregation, No collection policy." Therefore, all barangays are separating biodegradable from non-biodegradables. Currently, the city has two Environmental Recycling System (ERS) to process organic matter daily. However, only one ERS machine is operational that has a capacity of 24 tons daily, which is still not sufficient to accommodate all biodegradables, given the inevitable waste generation growth. Moreover, the yield compost of the said ERS is not stabilized and needs further treatment before it will be used in agriculture. Adding to the data above, only one barangay or village is doing community composting because of space availability but still have issues such as nuisance due to odor, rodents, and flies.

\subsection{Sampling design and technique}

A survey questionnaire and interview was carried out in the study area to engage household to primarily participate in the design of the waste bin and determine the factors affecting the level of composting Also, the preferred biodegradable waste management by the tenant as an intervention to help government's environmental recycling system. A total sample size of 384 households participated in the study. The sample size was determined using open epi online sample size calculator with a $95 \%$ level of confidence and then stratified random sampling was 
undertaken to determine equal proportion or representation from the 16 clustered barangays. By dividing the village/barangay's number of the household to the sample size drawn from each barangay, sampling intervals were derived. Only one respondent at each house was selected to join in the study. The questionnaire was divided into four parts. The first part is the sociodemographic profile of the respondent, the second part is for the composting status and current practice regarding biodegradables due to once a week collection, the third part is the preferred biowaste management level, and last part is the preferred design criteria of the waste bin. Permission was sought first from the authorities at "Liga ng mga Barangay" before conducting the study. All respondents were asked voluntary participation before it was explained the objective of the research and how the outcome will benefit them. The survey interview was conducted for one week from sampling areas, as shown in Figure 1 above.

\subsection{Compost Bin Design Criteria}

The compost bin physical and aesthetic design features as follows derived from related literature, observations, and issues on composting:

a) Capacity: Waste bin capacity varies based on the amount of waste generation and type of use (Lakhan, 2015; Tchobanoglous \& Kreith, 2002); i.e., For a small family size, a low capacity waste bin is used and larger volume for academic institutions (Tchobanoglous \& Kreith, 2002). The design capacity of various compartments is based mainly on the required storage volume (Chow, So, \& Cheung, 2016). Studies show that inappropriate and inadequate capacity, such as small size, resulting in poor collection efficiency (Pattnaik \& Reddy, 2010). Thus in this study, the researchers provided three variations (small, medium, large) of capacity with dimensions for the respondents to visualize and choose accordingly.

b) Color: The color-coded waste bin is usually associated with the type of garbage and it provides information to the people for easy disposal. Typically, green, blue, red, yellow, orange, grey, brown, white, and even transparent bin are used and vary in country or places, as shown in Table 1 below. The color can significantly contribute to increasing recycling and time spent in identifying the appropriate designated bin for that particular waste. However, some users are not satisfied with the color of the bin. According to McDonald \& Oates (2003), the color of the container is the main reason for the nonparticipation of the residents to the program and protested to be redesigned. In the Philippines, the colors green, red, blue and black is already mandated by RA 9003 "Ecological Solid Waste Management Act of 2000" specifically for biodegradables, recyclables, residuals, and special wastes, respectively (DENR, 2001). But, for this case, the above colors were not included in the survey to have a distinction from the norm because the waste bin was explicitly designed for the composting process and not for storage only. The color that was given to the respondent was cream, brown, gray, orange, and others for them to specify. Nevertheless, there's no universal rule regarding color. 
Table 1. Color coding of the organic waste bin from different countries

\begin{tabular}{|c|c|c|}
\hline Color & Place/Country & Reference \\
\hline \multirow{7}{*}{ Green } & Fuchu/Japan & $\begin{array}{c}\text { (Gotoh, Tanaka, \& Yonemura, } \\
1979)\end{array}$ \\
\hline & Los Angeles/California USA & (Chandler, 2004) \\
\hline & Puducherry/India & (Pattnaik \& Reddy, 2010) \\
\hline & Rushcliffe/United Kingdom & (Mee et al., 2004) \\
\hline & Wealden/CROWN/UK & (Woodard et al., 2001) \\
\hline & Sri Lanka & $\begin{array}{l}\text { (Lekammudiyanse \& } \\
\text { Gunatilake, 2009) }\end{array}$ \\
\hline & Thrace/Greece & $\begin{array}{c}\text { (Keramitsoglou \& Tsagarakis, } \\
\text { 2018) }\end{array}$ \\
\hline \multirow{5}{*}{ Brown } & Philippines & (DENR, 2001) \\
\hline & Brixworth/UK & $\begin{array}{c}\text { (Tonglet, Phillips, \& Read, } \\
\text { 2004) }\end{array}$ \\
\hline & Dorset/UK & $\begin{array}{c}\text { (Read, Gregory, \& Phillips, } \\
\text { 2009) }\end{array}$ \\
\hline & Germany & (Grenier, 2017) \\
\hline & Slovakia & (LIPTÁKOVÁ, 2017) \\
\hline Orange & $\begin{array}{lcc}\text { Oregon } & \text { State } & \text { University } \\
\text { Academic libraries } & \end{array}$ & (Hussong-Christian, 2016) \\
\hline Grey & Green bin system (Germany) & (Ball, 1990) \\
\hline
\end{tabular}

c) Mobility: The development of wheels became attractive because it reduces physical effort, enables quicker transportation, and requires lesser workforce (Chappells \& Shove, 1999). With these, the researcher offers three choices; no wheel, two-wheeled and fourwheeled, respectively.

d) Aeration: Ventilation/aeration is an essential factor to have aerobic digestion process (Gao et al., 2010; Raza \& Ahmad, 2016; Tchobanoglous, Theisen, \& Vigil, 1993; Topal, 2017). Various aeration techniques such as natural static pile ventilation, forced aeration, pile turning, and passive aeration are commonly used. Literature shows that aerated bin system improves biowaste management without gaseous emission (Puyuelo et al., 2013). Also, a study done by Karnchanawong \& Suriyanon (2011) shows that lateral and vertical systems natural ventilation makes wastes decay fastest in bins. Either way, both forced aeration and natural ventilation with pile turning have efficacy in final compost quality (Rasapoor, Adl, \& Pourazizi, 2016). Thereby, the researcher let the respondent choose between natural and forced or mechanically aerated waste bin. 
e) Odor filter: During composting or degradation process of organic matter, the undesirable odor is inevitable. To control composting smell, biofiltration method is suggested by (Park, Choi, \& Hong, 2002). The compost waste bin is designed in such a way that the exhaust air will pass through a biofiltering medium. In this case, participant's selects between natural odor filter (i.e., yield compost or soil) and synthetic odor filter (i.e., activated carbon, zeolite, and charcoal).

f) Opening and Closing: Biodegradable waste is placed every day and requires frequent opening and closing. In urban areas where everyone is busy, the yield compost product should be harvested every two weeks. Thus, either top or side for opening, closing, and harvesting are the available choices for the users.

g) Signage: One of the key elements to encourage users is an encouraging sign that provides clear information about the proper usage and purpose of the waste bin (Kelty et al., 2017; Meis \& Kashima, 2017; Poirier, Brain, \& Barajas, 2013).

h) Cost: This factor was included in determining how much stakeholders are willing to invest in the waste bin to be used for planning and analysis in the future.

\subsection{Statistical Analysis}

All data gathered from the survey questionnaire were transferred into SPSS version 20 to determine the descriptive result and their potential relationship. Frequency and Chi-square independence analysis with p-value $(<0.05)$ were used for different variables in sociodemographic profile and preferred waste bin design criteria's to evaluate whether there is an association between two variables. A linear regression analysis was performed to determine the relationship between population density and composting compliance. The formula to determine the composting compliance is shown below

$$
\text { Level of Composting Compliance }=\frac{\text { Number of respondents practicing composting }}{\text { Total number of Participants }}(1)
$$

\section{Results and Discussion}

\subsection{Socio-demographic profile of participants}

Table 2 below shows the socio-demographic profile of the respondents. A total of 384 participated in the survey and interview. The respondents were mostly young people (45.3\%), female $(55.5 \%)$, married $(47.1 \%)$, college graduate $(68 \%)$ and are Christians $(97.7 \%)$. In terms of dwelling type and ownership, about half of respondents have an entire property $(58.1 \%)$ in a private single family house $(59.6 \%)$. It also shows that more of the respondents belong to a family of four to six members. With regards to economic income, $65.9 \%$ of the household belongs to low-income household, while $29.7 \%$ are in the middle-income range, and only $4.4 \%$ of respondents fit to be high-income earners. 
Table 2. Socio-Demographic Profile

\begin{tabular}{|c|c|c|}
\hline Socio-Demographic Characteristics & $\begin{array}{c}\text { Number of } \\
\text { Participants } \\
(n=384)\end{array}$ & $\begin{array}{c}\text { Percentage } \\
(\%)\end{array}$ \\
\hline \multicolumn{3}{|l|}{ Age } \\
\hline Youth (18-30 yrs old) & 174 & 45.3 \\
\hline Adult (between 31-54 yrs old) & 155 & 40.4 \\
\hline Senior (55 yrs old and above) & 55 & 14.3 \\
\hline \multicolumn{3}{|l|}{ Sex } \\
\hline Male & 171 & 44.5 \\
\hline Female & 213 & 55.5 \\
\hline \multicolumn{3}{|l|}{ Marital Status } \\
\hline Single/Never Married & 180 & 46.9 \\
\hline Married & 181 & 47.1 \\
\hline Widowed/separated & 23 & 6 \\
\hline \multicolumn{3}{|l|}{ Educational Attainment } \\
\hline Elementary & 21 & 5.5 \\
\hline High School & 83 & 21.6 \\
\hline College & 261 & 68 \\
\hline Master & 16 & 4.2 \\
\hline Doctorate & 3 & 0.8 \\
\hline \multicolumn{3}{|l|}{ Religion } \\
\hline Christianity & 375 & 97.7 \\
\hline Islam & 4 & 1 \\
\hline Spiritist & 2 & 0.5 \\
\hline Atheist & 3 & 0.8 \\
\hline \multicolumn{3}{|l|}{ Ownership of Dwelling } \\
\hline Rent & 161 & 41.9 \\
\hline Complete ownership & 223 & 58.1 \\
\hline \multicolumn{3}{|l|}{ Type of Housing } \\
\hline High Rise Apartment & 32 & 8.3 \\
\hline Low Rise Apartment & 115 & 29.9 \\
\hline Private Single family house & 229 & 59.6 \\
\hline Others & 8 & 2.1 \\
\hline \multicolumn{3}{|l|}{ Respondent's Code } \\
\hline Head of the Family & 130 & 33.9 \\
\hline Mother & 103 & 26.8 \\
\hline Son/Daughter/Grandmother/Grandfather/Siblings & 151 & 39.3 \\
\hline \multicolumn{3}{|l|}{ Number of Households } \\
\hline One to Three members & 82 & 21.4 \\
\hline Four to Six members & 228 & 59.4 \\
\hline Seven and above members & 74 & 19.3 \\
\hline
\end{tabular}




\begin{tabular}{lcc}
\hline Monthly Income & & \\
Less than P 7,890 & 116 & 30.2 \\
P7,890-P15,789 & 137 & 35.7 \\
P15,780-P31,560 & 81 & 21.1 \\
P31,560-P78,900 & 33 & 8.6 \\
P78,900-P118,350 & 11 & 2.9 \\
P118,350-P157,800 & 3 & 0.8 \\
Above P157,800 & 3 & 0.8 \\
\hline
\end{tabular}

\subsection{Population density vs. compliance level in composting}

Most households are not interested since result shows 241 out 384 or $62.8 \%$ of respondents do not involve in composting as a means of managing biodegradable waste. Factors affecting household to the compliance level of composting were mainly lack of space (21.6\%) and because it requires extra time and work (20.1\%). Moreover, the lack of knowledge to composting aggravates the issue. The researchers found out that population density of the 16 clustered village/barangays has high significant $(\mathrm{p}<0.025)$ association to their composting compliance. With a more in-depth analysis, Figure 7 shows the linear regression relationship between these two variables. The $\mathrm{R}^{2}$ value of the regression line is 0.7382 showing that as population density increases, the more likely that household will not engage in the composting process. This is also due to lack of space mentioned above as the main reason why home does not participate in composting.

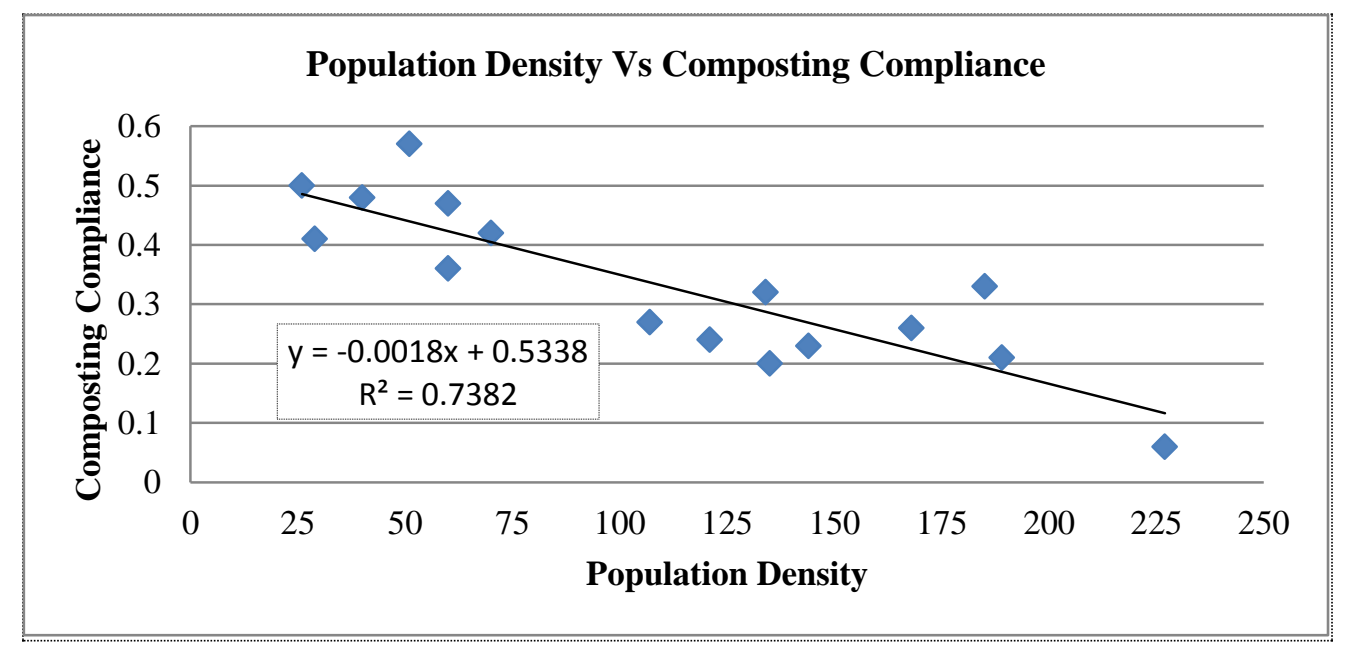

Figure 7. Regression analysis of population density and composting compliance

\subsection{Compost waste bin features}

The result showed in Table 3 that in terms of physical parameters, a color grey with medium drum capacity (15-inch diameter) and signage of "Biowaste Environmental Bin" is most prevalent in the survey. With regards to the mechanical aspect, four-wheeled device that open and close at the top is preferred. Moreover, either natural aeration (with holes) or forced ventilation and natural or synthetic odor filter can be chosen since percentage results were closed 
to each other. Most of them want the waste bin to be freely given to them as most of the household have low household income.

Table 3. Preferred features of the compost waste bin

\begin{tabular}{|c|c|c|}
\hline Design Parameters & $\begin{array}{c}\text { frequency } \\
(n=384)\end{array}$ & $\begin{array}{c}\text { Percentage } \\
(\%)\end{array}$ \\
\hline \multicolumn{3}{|l|}{ Capacity } \\
\hline $\begin{array}{l}\text { Small Drum(30-35 kgs, } 10 \text { inch } \\
\text { diameter) }\end{array}$ & 109 & 28.4 \\
\hline $\begin{array}{l}\text { Medium Drum( } 80-100 \mathrm{kgs}, 15 \text { inch } \\
\text { diameter) }\end{array}$ & 185 & 48.2 \\
\hline $\begin{array}{l}\text { Large Drum( } 200 \mathrm{kgs}, 23 \text { inch } \\
\text { diameter) }\end{array}$ & 90 & 23.4 \\
\hline \multicolumn{3}{|l|}{ Mobility } \\
\hline Two-wheeled & 110 & 28.6 \\
\hline Four-wheeled & 224 & 58.3 \\
\hline No wheel & 50 & 13 \\
\hline \multicolumn{3}{|l|}{ Aeration/Ventilation } \\
\hline Natural Aeration (with holes) & 205 & 53.4 \\
\hline $\begin{array}{l}\text { Mechanical/Forced Aeration (without } \\
\text { holes but with fan) }\end{array}$ & 179 & 46.6 \\
\hline \multicolumn{3}{|l|}{ Odor filter } \\
\hline Natural (Compost/soil/sawdust) & 181 & 47.1 \\
\hline Synthetic (Activated Carbon/zeolite) & 203 & 52.9 \\
\hline \multicolumn{3}{|l|}{ Colour } \\
\hline Cream & 38 & 9.9 \\
\hline Brown & 98 & 25.5 \\
\hline Grey & 111 & 28.9 \\
\hline Orange & 61 & 15.9 \\
\hline Any & 13 & 3.4 \\
\hline Green & 29 & 7.6 \\
\hline Black & 19 & 4.9 \\
\hline Red & 2 & 0.5 \\
\hline Blue & 4 & 1 \\
\hline Pink & 2 & 0.5 \\
\hline Peach & 2 & 0.5 \\
\hline White & 2 & 0.5 \\
\hline Yellow & 3 & 0.8 \\
\hline \multicolumn{3}{|l|}{ Opening and Closing } \\
\hline Top & 295 & 76.8 \\
\hline Side & 89 & 23.2 \\
\hline \multicolumn{3}{|l|}{ Preferred Signage of the bin } \\
\hline Bio Diversion Waste Bin & 44 & 11.5 \\
\hline Bio Recycling Waste Bin & 108 & 28.1 \\
\hline
\end{tabular}




\begin{tabular}{lcc} 
Bio Environmental Waste Bin & 183 & 47.7 \\
Bio Recovery Waste Bin & 41 & 10.7 \\
Without signage & 7 & 1.8 \\
Others & 1 & 0.3 \\
\hline Cost & 258 & \\
Free & 77 & 67.2 \\
3000 pesos & 24 & 20.1 \\
5000 pesos & 6 & 6.3 \\
7000 pesos & 19 & 1.6 \\
Others & & 4.8 \\
\hline
\end{tabular}

The Figure 8 below shows the generated bio waste bin from the respondents in all clustered barangays in Baguio City. The bin has two layers as shown in figure 8.b with leachate catcher located at the bottom portion. The top layer bin will accommodate the food or kitchen waste generated daily until it will be filled up full. After that, it will be transferred at the bottom part in which the empty bin will be the one to be placed at the top for replacement.

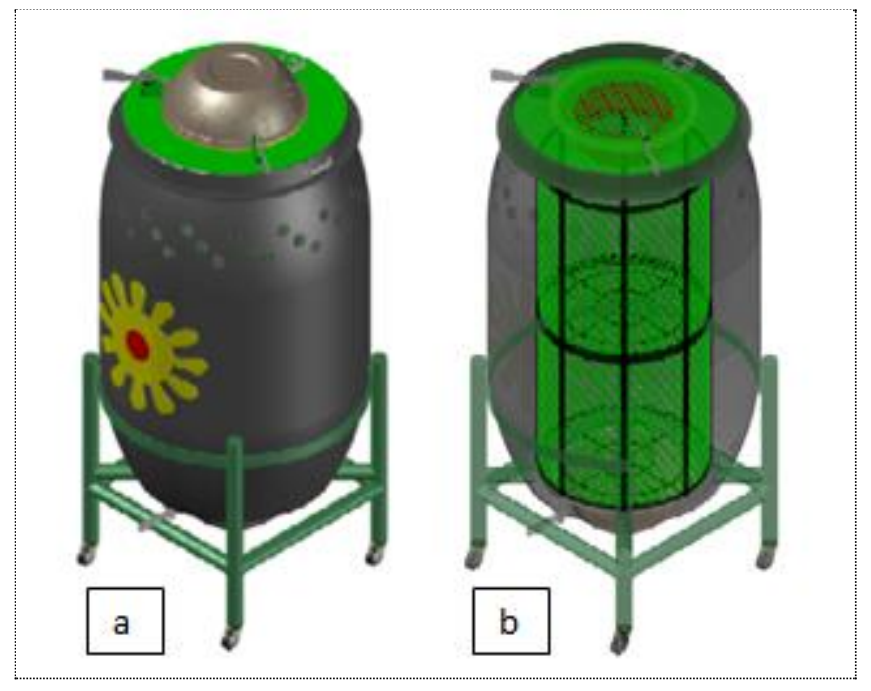

Figure 8. a. Generated waste bin design b. Inside features of the bin

\subsection{Preferred household biodegradable waste management scheme}

Most respondents believed that it's a collective effort between household and barangay officials in managing their biodegradable waste. Table 4 and Figure 8 below show the frequency of their reaction to the preferred management scheme as a support for the city's waste management endeavor. However, $18.2 \%$ of the household wants the barangay officials to managed bio waste due to lack of space, no time, and no knowledge about it as stated in the result of the statistical analysis. Lastly, only $14.3 \%$ of respondent's wants that it should be managed at the source.

Table 4. Preferred management level for biowaste 


\begin{tabular}{lcc}
\hline & $\begin{array}{c}\text { Frequency } \\
(\mathrm{N}=384)\end{array}$ & $\begin{array}{c}\text { Percentage } \\
(\%)\end{array}$ \\
\cline { 2 - 3 } Household level only & 55 & 14.3 \\
Barangay level only & 70 & 18.2 \\
Both household and barangay & 259 & 67.4 \\
\hline
\end{tabular}



Figure 8. Shows the doughnut chart of preferred biodegradable management scheme

Most of the reason in choosing both household and barangay are the words "coordination, more effective, ensure better and proper management, cooperation, quality checked by the barangay, responsibility of both, help each other, teamwork, to be more productive, no space in household, easier, both will benefit, implement, eco-friendly, organized, less pollution, discipline, efficient, lessen trash, participation, clean community, improve cleanliness, assimilate task, better output, partnership, knowledge, easier segregation, guide and educate, encourage, difficult job, compliance of RA 9003, community job". Figure 9 below shows the common words as their response during the interview.

Those participants who want that their biodegradables be managed only at the barangay are the ones who are renting and do not have time for this kind of system. While those who want that it should be the household level, are the ones who acknowledge that they should be responsible for their wastes. With these, the researchers have proposed framework in managing biodegradable waste for both household and community/barangay level as shown in the Figure $\mathbf{1 0}$ below. 


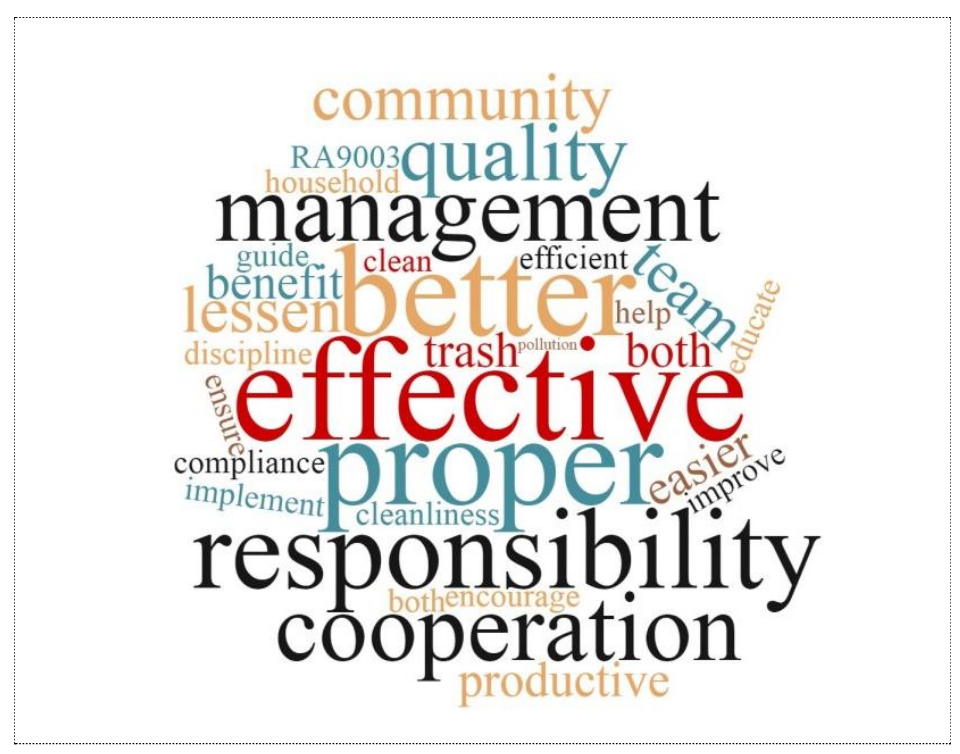

Figure 9. Collective keywords during the interview

The proposed framework below shows the management of organic matter to satisfy the preferred management level of the households. It gives option to families whether to manage their waste at the source by using the generated design of waste bin or be given to barangay so that the village officials will be the one to handle. For households that do not have any space and time to manage their own bio waste may be processed in the barangay through the rotary drum composter. The rotary drum composter is a type of in vessel composting device which can process degradable waste into valuable compost. This kind of system is usually appropriate for limited spaces in urban city of Baguio. According to the result above, both household and barangay should work together for the system to be effective and sustainable.

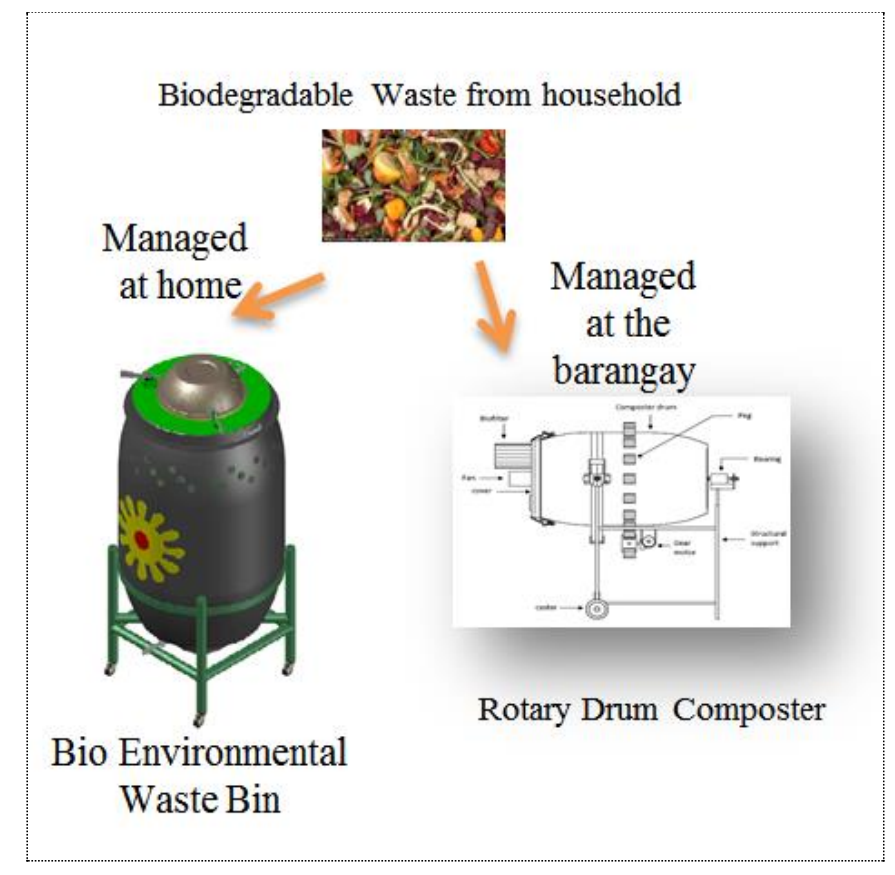


Figure 10. Proposed framework for biodegradable waste management

\subsection{Summary of data with significant association}

Table 5. Cross-tabulation of independent variables

\begin{tabular}{|c|c|c|c|c|c|c|c|c|c|c|c|}
\hline \multirow{3}{*}{ Parameters } & \multicolumn{11}{|c|}{ Pearson Chi-square Asymptotic significance ( 2 sided) } \\
\hline & \multicolumn{11}{|c|}{ Sociodemographic variables } \\
\hline & $\begin{array}{l}\text { Age } \\
\text { group }\end{array}$ & Sex & $\begin{array}{c}\text { Marita } \\
1 \\
\text { Status }\end{array}$ & $\begin{array}{c}\text { Educat } \\
\text { ion }\end{array}$ & $\begin{array}{l}\text { Reli } \\
\text { gion }\end{array}$ & $\begin{array}{l}\text { Dwelling } \\
\text { Owner } \\
\text { ship }\end{array}$ & $\begin{array}{c}\text { Housing } \\
\text { type }\end{array}$ & $\begin{array}{l}\text { Respon- } \\
\text { dents } \\
\text { Code }\end{array}$ & $\begin{array}{c}\text { No of } \\
\text { House- } \\
\text { hold }\end{array}$ & Income & $\begin{array}{l}\text { Pop } \\
\text { Den }\end{array}$ \\
\hline $\begin{array}{l}\text { Engagement } \\
\text { in } \\
\text { composting }\end{array}$ & $* 0.005$ & 0.481 & $* 0.035$ & 0.386 & 0.352 & $* 0.003$ & $* 0.015$ & 0.73 & 0.138 & 0.6 & $\begin{array}{c}* 0.02 \\
5\end{array}$ \\
\hline $\begin{array}{l}\text { Preferred } \\
\text { Biowaste } \\
\text { Management } \\
\text { Scheme }\end{array}$ & 0.231 & 0.053 & 0.068 & $* 0.007$ & 0.497 & 0.916 & 0.72 & 0.05 & 0.334 & 0.378 & ----- \\
\hline $\begin{array}{l}\text { Waste Bin } \\
\text { Features }\end{array}$ & & & & & & & & & & & \\
\hline Capacity & $* 0.014$ & 0.162 & 0.811 & 0.68 & 0.431 & 0.118 & 0.194 & 0.229 & 0.783 & 0.118 & ----- \\
\hline Color & 0.93 & 0.61 & 0.138 & $* 0.001$ & 0.996 & 0.139 & $* 0.027$ & 0.443 & 0.469 & $* 0.002$ & ----- \\
\hline Mobility & 0.111 & 0.368 & 0.872 & 0.364 & 0.936 & 0.623 & 0.678 & 0.051 & 0.629 & 0.344 & ------ \\
\hline Aeration & 0.576 & $* 0.011$ & 0.766 & 0.631 & 0.61 & 0.992 & 0.572 & 0.127 & 0.461 & 0.171 & ------ \\
\hline $\begin{array}{l}\text { Odor Filter } \\
\text { Opening and }\end{array}$ & 0.161 & $* 0.048$ & 0.578 & 0.73 & 0.115 & 0.519 & 0.567 & $* 0.024$ & 0.408 & 0.38 & ----- \\
\hline Closing & 0.974 & 0.929 & 0.437 & 0.239 & 0.448 & 0.747 & 0.685 & 493 & 0.635 & 0.288 & ------ \\
\hline Signage & $* 0.001$ & 0.656 & $* 0.015$ & 0.293 & 0.893 & 0.063 & 0.075 & $* 0.017$ & 0.711 & 0.184 & ------ \\
\hline Cost & 0.655 & 0.541 & 0.977 & 0.928 & 0.82 & 0.946 & 0.61 & 0.224 & 0.752 & 0.548 & ----- \\
\hline
\end{tabular}

*p value $<0.05$ (95\% Confidence Level)

The table above shows the different factors that have a significant association to study parameters. Parameter such as engagement in composting has association towards age group, marital status, dwelling ownership, type of housing, and population density. For the preferred biowaste management system, only education attainment of the respondents was related. Waste bin features such as capacity have a clear association with age groups. Color of the bin is linked to educational attainment, housing type, and monthly income of the participants. The preferred aeration has a connection to sex. Odor filter, on the other hand, has affected by both sex and respondents code. Moreover, signage was associated with age groups, marital status, and respondent's code. Lastly, the preference of the participants regarding mobility, opening and closing, and cost doesn't have any relationship to the socio-demographic characteristics of the respondents.

Result shows (see other files attached) that young and adult respondents are not engaging to composting while those in senior age are more into composting. In terms of marital status, whether the respondents are married, widowed, or single, most of them don't practice composting. Regarding dwelling ownership and type of housing, those who own their houses in single-detached type are more likely engaged in composting. However, most household still does 
not practice this kind of procedure because of limited space availability that was linked to higher population density in the area. In terms of capacity and signage of waste bin, all age groups have chosen medium drum/barrel size and biowaste environmental bin signage, respectively. In reference also to aeration and odor filter, most males are clinging into mechanical aeration while female wants aeration naturally. Similarly, most female like natural odor filter while more male is into synthetic ones. With regards to Color, college graduates prefer greyish color, but those who are residing in private single-family house wants the design color to be brown. Regardless of the income level of respondents, grey color is still their preference. Finally, concerning preferred signage, all respondent's whether young, adult, senior that was single, married or widowed chose mostly "biowaste environmental bin" because of the keyword that has something related to the environment.

\section{Conclusion and Recommendations}

This study confirms that lack of space due to high population density restricts household members and the barangay to comply with the existing law with regards to composting. Moreover, the underlying factors associated with the study parameters were affected by the respondent's characteristics, location, and position. Community involvement or participation in designing scheme at the initial planning stage can play a significant role in the success or effectiveness of managing biowaste at the source in order to reduce costs of collecting and hauling biodegradables wastes, which can also increase segregation efficiency to an extent. Furthermore, it provides alternative options to city waste planners in handling organic waste in which homeowners can be able to join in the environmental endeavors of the city thru this generated design of waste bin. For it to be sustainable, careful analysis and evaluation of waste bin is a must. The researcher recommends the fabrication and deployment of the waste bin for pilot testing and cost-benefit analysis. It is not the intention of the researchers to imply that the study and its result is representing the problem of waste disposal in the country, much less, the entire world. It is our humble desire to share a practical mechanism of managing pile-up of garbage in our community.

\section{Acknowledgment}

The authors would like to thank the Department of Science and Technology (DOST PCCIERD) for funding this research. Also, the writers would like thank also University of the Philippines Los Banos (UPLB) and Saint Louis University (SLU) for being the host and sending institution, respectively. Lastly, the researchers are thankful to the League of Barangay and Solid Waste Management in Baguio City for the support during the survey interview.

\section{Appendix A. Supplementary Data}

Supplementary materials related to this article can be found at the attached file under table (s)

\section{References}

ADB. (2017). Intergrated Solid Waste Management for Local Governments A practical Guide. Asian Development Bank. https://doi.org/http://dx.doi.org/10.22617/TIM178662-2 
Adhikari, B. K., Trémier, A., Martinez, J., \& Barrington, S. (2012). Home composting of organic waste - Part 1: Effect of home composter design. International Journal of Environmental Technology and Management, 15(3-6), 417-437. https://doi.org/10.1504/IJETM.2012.049238

Baguio City Government. (2015). Ten-Year Ecological Solid Waste Management Plan (20152024). Baguio City.

BaguioCity Planning and Development Office. (2014). Comprehensive Land Use Plan of Baguio City for 2014-2023. Baguio City.

Ball, R. (1990). Glass recycling by source separation from municipal wastes. Resources, Conservation and Recycling, 4(1-2), 63-75.

Castillo, A. L., \& Otoma, S. (2013). Status of Solid Waste Management in the Philippines. In Proceedings of the Annual Conference of Japan Society of Material Cycles and Waste Management The 24th Annual Conference of Japan Society of Material Cycles and Waste Management (p. 677). Japan Society of Material Cycles and Waste Management.

Cerda, A., Artola, A., Font, X., Barrena, R., Gea, T., \& Sánchez, A. (2018). Composting of food wastes: Status and challenges. Bioresource Technology. https://doi.org/10.1016/j.biortech.2017.06.133

Chandler, N. (2004). The bin stops here. Waste Age.

Chappells, H., \& Shove, E. (1999). Bins and the history of waste relations. Reader for Lancaster Summer School. Available at: Http://Www. Comp. Lancs. Ac. Uk/Sociology/Esf/Bins. Htm.

Chow, C., So, W.-M. W., \& Cheung, T.-Y. (2016). Research and development of a new waste collection bin to facilitate education in plastic recycling. Applied Environmental Education \& Communication, 15(1), 45-57.

Crossette, B. (1998). The great hill stations of Asia. Basic Books (AZ).

DENR. Prescribing Guidelines on Cleanliness and Orderliness Within DENR Premises., Pub. L. No. DENR Memorandum Order No. 2001 - 11, 478 (2001). Philippines.

DENR. (2019). The status of closed irisan dumpsite of LGU Baguio.

Doronila, A. (2009). Analysis: Baguio city's renewal rests on its uniqueness. Philippine Daily Inquirer 15 June.

EMB - DENR. (2015). National Solid Waste Management Status Report (2008-2014). Retrieved from http://119.92.161.2/portal/Portals/38/Solid Wastefinaldraft 12.29.15.pdf

Estoque, R. C., \& Murayama, Y. (2013a). City profile: Baguio. Cities, 30, 240-251.

Estoque, R. C., \& Murayama, Y. (2013b). Landscape pattern and ecosystem service value changes: Implications for environmental sustainability planning for the rapidly urbanizing summer capital of the Philippines. Landscape and Urban Planning, 116, 60-72.

Estoque, R. C., \& Murayama, Y. (2014). Measuring sustainability based upon various perspectives: a case study of a hill station in Southeast Asia. Ambio, 43(7), 943-956. 
Fan, Y. Van, Lee, C. T., Klemeš, J. J., Chua, L. S., Sarmidi, M. R., \& Leow, C. W. (2018). Evaluation of Effective Microorganisms on home scale organic waste composting. Journal of Environmental Management, 216. https://doi.org/10.1016/j.jenvman.2017.04.019

Gao, M., Liang, F., Yu, A., Li, B., \& Yang, L. (2010). Evaluation of stability and maturity during forced-aeration composting of chicken manure and sawdust at different $\mathrm{C} / \mathrm{N}$ ratios. Chemosphere, 78(5), 614-619.

Gonzales, L. B. F. (2016). Urban Sprawl : Extent and Environment impact in Baguio City, Philippines, 504(36), 7-14. https://doi.org/10.2298/SPAT1636007G

Gotoh, S., Tanaka, E., \& Yonemura, Y. (1979). Source separation for resource recovery-Stateof-the-art. Conservation \& Recycling, 3(3-4), 305-317.

Grenier, E. (2017). Guide to separating trash in Germany. Retrieved May 29, 2019, from https://www.dw.com/en/guide-to-separating-trash-in-germany/g-38830796

Guidoni, L. L. C., Marques, R. V., Moncks, R. B., Botelho, F. T., da Paz, M. F., Corrêa, L. B., \& Corrêa, É. K. (2018). Home composting using different ratios of bulking agent to food waste. Journal of Environmental Management, 207. https://doi.org/10.1016/j.jenvman.2017.11.031

Harrison, E. Z. (2007). HEALTH IMPACT OF COMPOSTING AIR EMISSIONS. BioCycle, $48(11), 44$.

Hussong-Christian, U. (2016). If you build it, will they sort it? Compost collection in the academic library learning commons. Library Management, 37(6/7), 340-351.

Karnchanawong, S., \& Suriyanon, N. (2011). Household organic waste composting using bins with different types of passive aeration. Resources, Conservation and Recycling, 55(5), 548-553.

Kelty, A. L., Dias, C. S., Cammarata, D. J., \& Cevallos, M. A. (2017). Sustainability at WPI: Food Waste Management.

Keramitsoglou, K. M., \& Tsagarakis, K. P. (2018). Public participation in designing the recycling bins to encourage recycling. Sustainability (Switzerland), 10(4), 16-18. https://doi.org/10.3390/su10041240

Lakhan, C. (2015). Evaluating the effects of unit based waste disposal schemes on the collection of household recyclables in Ontario, Canada. Resources, Conservation and Recycling, 95, $38-45$.

Lekammudiyanse, L., \& Gunatilake, S. K. (2009). Efficiency of the household compost bin as a wastemanagement technique in Sri Lanka. International Journal of Basic and Applied Sciences IJBAS-LIENS, 10(54), 89-94.

Lim, C. Y. (2015). Food waste issues are causing a stink. Star Media Group Berhad, p. 1.

LIPTÁKOVÁ, J. (2017). Sorting out biodegradable waste. Retrieved May 29, 2019, from https://spectator.sme.sk/c/20437408/sorting-out-biodegradable-waste.html

Masebinu, S. O., Akinlabi, E. T., Muzenda, E., Mbohwa, C., Aboyade, A. O., \& Mahlatsi, T. 
(2016). Environmental sustainability: Multi-criteria decision analysis for resource recovery from organic fraction of municipal solid waste. In IEEE International Conference on Industrial Engineering and Engineering Management (Vol. 2016-December, pp. 15431547). IEEE Computer Society. https://doi.org/10.1109/IEEM.2016.7798136

McDonald, S., \& Oates, C. (2003). Reasons for non-participation in a kerbside recycling scheme. Resources, Conservation and Recycling, 39(4), 369-385.

Mee, N., Clewes, D., Phillips, P. S., \& Read, A. D. (2004). Effective implementation of a marketing communications strategy for kerbside recycling: a case study from Rushcliffe, UK. Resources, Conservation and Recycling, 42(1), 1-26.

Meis, J., \& Kashima, Y. (2017). Signage as a tool for behavioral change: Direct and indirect routes to understanding the meaning of a sign. PloS One, 12(8), e0182975.

Oliveira, L. S. B. L., Oliveira, D. S. B. L., Bezerra, B. S., Silva Pereira, B., \& Battistelle, R. A. G. (2017). Environmental analysis of organic waste treatment focusing on composting scenarios. Journal of Cleaner Production, 155. https://doi.org/10.1016/j.jclepro.2016.08.093

Onwosi, C. O., Igbokwe, V. C., Odimba, J. N., Eke, I. E., Nwankwoala, M. O., Iroh, I. N., \& Ezeogu, L. I. (2017). Composting technology in waste stabilization: On the methods, challenges and future prospects. Journal of Environmental Management. https://doi.org/10.1016/j.jenvman.2016.12.051

Park, K. J., Choi, M. H., \& Hong, J. H. (2002). Control of composting odor using biofiltration. Compost Science \& Utilization, 10(4), 356-362.

Pattnaik, S., \& Reddy, M. V. (2010). Assessment of municipal solid waste management in Puducherry (Pondicherry), India. Resources, Conservation and Recycling, 54(8), 512-520.

Pergola, M., Persiani, A., Palese, A. M., Di Meo, V., Pastore, V., D’Adamo, C., \& Celano, G. (2018). Composting: The way for a sustainable agriculture. Applied Soil Ecology, 123. https://doi.org/10.1016/j.apsoil.2017.10.016

Poirier, M., Brain, R., \& Barajas, E. (2013). Strategies to improve recycling in natural areas: Examples from Zion National Park.

Practical Action South Asia. (2008). Home Composting Bins. Practical Action, The Schumacher Centre for Technology and Development, 9 . Retrieved from https://solucionespracticas.org.pe/Descargar/537/4990

Puyuelo, B., Colón, J., Martín, P., \& Sánchez, A. (2013). Comparison of compostable bags and aerated bins with conventional storage systems to collect the organic fraction of municipal solid waste from homes. A Catalonia case study. Waste Management, 33(6), 1381-1389. https://doi.org/https://doi.org/10.1016/j.wasman.2013.02.015

Rasapoor, M., Adl, M., \& Pourazizi, B. (2016). Comparative evaluation of aeration methods for municipal solid waste composting from the perspective of resource management: A practical case study in Tehran, Iran. Journal of Environmental Management, 184, 528-534.

Raza, S., \& Ahmad, J. (2016). Composting process: a review. International Journal of Biological 
Research; Vol 4, No 2 (2016)DO - 10.14419/Ijbr.V4i2.6354 . Retrieved from https://www.sciencepubco.com/index.php/IJBR/article/view/6354/2339

Read, M., Gregory, M. K., \& Phillips, P. S. (2009). An evaluation of four key methods for monitoring household waste prevention campaigns in the UK. Resources, Conservation and Recycling, 54(1), 9-20.

Reed, R. R. (1999). City of pines : the origins of Baguio as a colonial hill station and regional capital (2nd ed.). Baguio City: A-Seven Publishing.

Sapuay, G. P. (2005). Ecological Solid Waste Management Act of 2000 (RA 9003): a major step to better solid waste management in the Philippines. In International Conference on Integrated Solid Waste Management in Southeast Asian Cities, Siem Reap (pp. 51-59).

Tchobanoglous, George; Kreith, F. (2002). Handbook of Solid Waste Management (2nd Editio). McGraw-Hill. https://doi.org/DOI: 10.1036/0071356231

Tchobanoglous, G., Theisen, H., \& Vigil, S. A. (1993). Integrated solid waste management: engineering principles and management issues. New York, New York, USA.

Tonglet, M., Phillips, P. S., \& Read, A. D. (2004). Using the Theory of Planned Behaviour to investigate the determinants of recycling behaviour: a case study from Brixworth, UK. Resources, Conservation and Recycling, 41(3), 191-214.

Topal, M. (2017). Determination of the Effect of Aeration Rate on Composting of Vegetable Fruit Wastes Determination of the Effect of Aeration Rate on Composting of Vegetable Fruit Wastes, (November 2011). https://doi.org/10.1002/clen.201000537

Vázquez, M. A., \& Soto, M. (2017). The efficiency of home composting programmes and compost quality. Waste Management, 64. https://doi.org/10.1016/j.wasman.2017.03.022

Wilmink, T. R., \& Diener, R. G. (2001). Handbook for Commercial and Municipal Composting in West Virginia. Wilmink Associates.

Woodard, R., Harder, M. K., Bench, M., \& Philip, M. (2001). Evaluating the performance of a fortnightly collection of household waste separated into compostables, recyclates and refuse in the south of England. Resources, Conservation and Recycling, 31(3), 265-284.

World Bank. (2019). Solid Waste Management. Retrieved April 1, 2019, from www.worldbank.org/en/topic/urbandevelopment/brief/solid-waste-management 